\title{
Keterampilan Guru Dalam Bertanya Pada Pembelajaran Matematika
}

\author{
Mariam Nasution* \\ Email: mariam@iain-padangsidimpuan.ac.id \\ Fakultas Tarbiyah dan Ilmu Keguruan IAIN Padangsidimpuan
}

\begin{abstract}
In learning mathematics the questioning skills are very much needed in order to carry out the teaching and learning process in the classroom. Skills to ask, for a teacher is a very important skill to master. The skill of asking is an integral part in order to improve the quality of learning processes and outcomes, which is also part of the success in instructional management and classroom management. Through the skill of asking the teacher is able to detect obstacles in the process of thinking among students and can improve and improve the learning process among students. The questions that are conveyed must pay attention to the components, the skill component to ask. Therefore the questioning skills can be divided into two groups, namely basic questioning skills and advanced questioning skills. Basic questioning skills are: (1) Clear and concise, (2) Provision of references, (3) Concentration, (4) Transfer of turn, (5) Distribution, (6) Giving time to think (7) Giving guidance. Advanced questioning is: (1) Changing cognitive level guidance (2) Setting the order of questions, (3). Tracking questions, and (4) Encouraging interaction
\end{abstract}

Keywords: the questioning skills, learning mathematics, pausing, prompting, probing

\begin{abstract}
Abstrak
Dalam pembelajaran matematika keterampilan bertanya sangat di perlukan dalam rangka melakukan proses belajar mengajar di kelas. Keterampilan bertanya, bagi seorang guru merupakan keterampilan yang sangat penting untuk dikuasai. Keterampilan bertanya dilakukan guru dalam rangka meningkatkan kemampuan peserta didik dalam menguasai bahan ajar serta dapat melatih siswa berkomunikasi secara lisan maupun tulisan. Pertanyaan-pertanyaan yang dikemukakan guru hendaknya sesuai dengan tingkat usia dan jenjang pendidikannya. Pertanyaan yang diajukan guru akan dapat menjadi tolak ukur untuk melihat sejauh mana tujuan pembelajaran yang sudah tercapai. Pertanyaan yang di sampaikan harus memperhatikan komponen;komponen keterampilan bertanya. Oleh sebab itu keterampilan bertanya dapat dibagi menjadi 2 kelompok yaitu keterampilan bertanya dasar dan keterampilan bertanya lanjutan. Keterampilan bertanya dasar yaitu: (1) Singkat dan jelas,(2) Pemberian acuan,(3) Pemusatan,(4) Pemindahan giliran,(5) Penyebaran, (6) Pemberian waktu berpikir (7) Pemberian tuntunan. Keteramapilan bertanya lanjutan yaitu: (1) Pengubahan
\end{abstract}

${ }^{*}$ Correspondence:

Email: mariam@iain-padangsidimpuan.ac.id 
tuntunan tingkat kognitif (2) Pengaturan urutan pertanyaan, (3). Pertanyaan pelacak, dan (4) Mendorong terjadinya interaksi.

Kata Kunci: keterampilan bertanya, pembelajaran matematika, pausing, prompting, probing

\section{A. PENDAHULUAN}

Dalam proses pembelajaran matematika guru sebagai organisator atas berlangsungnya proses belajar mengajar. Belajar dapat berhasil apabila guru dan siswa dapat melakukan berbagai aktivitas yang menunjang pembelajaran di kelas dalam rangka mencapai tujuan pembelajaran. Oleh sebab itu, guru sebagai garda terdepan dalam mengarahkan siswa dalam berbagai kegiatan yang dilakukan. Dalam hal ini berbagai keterampilan dan tanggung jawab guru yang sangat utama di perlukan dalam menyampaikan pembelajaran matematika. Sebagai seorang guru matematika bukan saja dapat menguasai ilmu pengetahuan dalam bidang matematika, tetapi harus mampu melakukan berbagai keterampilan-keterampilan dalam menyampaikan pembelajaran di ruagan kelas. Tugas guru secara umum adalah mendidik. Dalam operasionalisasinya, mendidik adalah rangkaian proses mengajar, memberikan dorongan, memuji, menghukum, membentuk contoh dan membisakan.

Guru sebagai pendidik yang mempunyai tugas bukan saja sebagai model di depan kelas tetapi harus mampu menjadikan peserta didik dapat belajar dalam suasana yang nyaman dan kondusif sehingga pembelajaran dapat berlangsung dengan baik. Guru mempunyai tugas sebagai pengajar yang meliputi bidang mendidik, mengajar dan melatih keterampilan. Mendidik siswa merupakan tugas seorang guru yang dapat mengubah prilaku peserta didik kearah yang lebih positif atau lebih baik dan mengajarkan tatanan nilai agar peserta didik dapat melajutkan kehidupanya di tengah masyarakat yang berguna bagi bangsa dan negara. Dalam mengajar terdapat suatu proses interaksi antara guru dengan peserta didik serta mentransferkan ilmu pengetahuan sehingga tujuan pembelajaran dapat di kuasai oleh siswa. Proses melatih dapat diartikan membiasakan peserta didik untuk dapat melakukan hal-hal yang baik agar keterampilan-keterampilan siswa dapat terbina Sesuai pendapat yang diungkapkan Peters yang dikutip Sudjana, bahwa tanggung jawab dan tugas guru, yaitu: (a) Guru sebagai pendidik sekaligus pengajar bagi peserta didik, (b) Guru sebagai pelatih dan pembimbing dalam kegiatan belajar, dan (c) guru sebagai fasilitaor dan administrator dalam proses belajar mengajar ${ }^{1}$. Tugas guru yang di jelaskan di atas merupakan tugas profesi seorang guru yang harus dilaksanakan dengan sebai-baiknya. Guru sebagai pendamping peserta didik dalam proses pembelajaran pengajar lebih lebih mengutamakan tugas dalam melakukan pelaksanaan pembelajaran,memberikan model atau metode yang inovatif dalam kegiatan belajar serta dapat mengevaluasi kemampuan siswa.. Guru sebagai pelatih dan pembimbing dapat memberi latihan-latihan serta mengarahkan setiap tindakan yang dilakukan peserta didik dalam kegiatan belajar. Sedangkan guru sebagai fasilitator dan administrator dikelas hendaknya dapat

\footnotetext{
${ }^{1}$ Sudjana. Metoda Statistika. Edisi ke VI (Bandung: Tarsito,2002), hlm 15.
} 
memberikan pelayanan yang baik dan menyediakan keperluan atau alat-alat penting utuk kepentingan keberlangsungan pembelajaran..

Hal senada di ungkapkan Hamalik, tanggung jawab guru, yaitu ${ }^{2}$ :

1. Murid-murid di tuntut agar mampu belajar dengan baik .Tanggung jawab guru yang terpenting adalah merencanakan, melaksanakan dan menuntut murid-murid melakukan kegiatan-kegiatan yang menunjang agar peserta didik dapat memperoleh ilmu pengetahuan. Guru juga harus mampu membalajarkan siswanya.

2. Ikut serta dalam pembinaan kurikulum sekolah. dalam rangka meningkatkan mutu dari isi suatu pedoman pengajaran. Kurikulum yang bagus akan dapat meningkatkan mutu Pendidikan secara local maupun nasional bahkan harus dapat mengikuti tingkat perkebangan secara internasional.

3. Pembinaan secara kontinu terhadap diri siswa (prilaku, mental dan pisik).

4. Pemberian arahan secara terbimbing kepada murid. Mengarahkan sekaligus membimbing peserta didik dalam kegiatan belajar sangat di sarankan agar siswa mampu menemukan bagaimana persoalan dapat di pecahkan.

5. Mendiagnosis kesulitan-kesulitan belajar yang dialami peserta didik dan mengatasi kelemahan-kelemahan dalam menguasai materi pembelajaran.

6. Melakukan penelitian. Guru bukan saja bergerak di bidang pengajaran tetapi harus mampu melakukan penelitian di bidannya masing-masing yang bertujuan untuk dapat memperbaiki kualitas pendidikan.

7. Aktif dalam masyarakat. Seorang guru yang tidak aktif dalam masyarakat tidak akan dapat melihat tingkat perkembangan pendidikan di lingkungan dan masyarakatnya. Oleh karena itu guru semestinya berperan aktif dan bersosial di masyarakat dalam rangka melihat bagaimana kemajuan pendidikan dan ketertinggalannya.

Tanggung jawab guru sangat perlu di tingkatkan dalam rangka meningkatkan peranan dan kemampuan di bidang paedagogik maupun bidang profesional. Kecakapan yang bervariasi dan keterampilan yang maksimal harus dimiliki guru untuk dapat melaksanakan fungsinya sebagai guru yang berdedikasi tinggi dalam rangka mencapai tujuan pembelajaran. Wijaya dkk, menyebutkan beberapa tanggung jawab yang memerlukan sejumlah kemampuan yang lebih khusus dari seorang guru, yaitu ${ }^{3}$ :

1. Tanggung jawab dalam bentuk moral adalah seorang guru dalam bertindak atau berbuat harus sesuai dengan etika dan norma-norma yang berlaku di dalam masyarakat dan negara.

2. Tanggung jawab dalam bidang pendidikan di sekolah adalah setiap guru harus menguasai cara belajar-mengajar yang efektif, mampu membuat satuan pelajaran, mampu dan memahami kurikulum dengan baik, mampu mengajar dikelas, mampu menjadi model bagi siswa, mampu memberikan nasihat, menguasai teknik-teknik pemberian bimbingan dan layanan, mampu memberikan saran dan prasana, mampu membuat dan melaksanakan evaluasi dan lain-lain.

${ }^{2}$ Hamalik, Dasar-dasar Pengembangan Kurikulum. Cet. III (Bandung: Remaja Rosda Karya.2004), hlm. 175.

${ }^{3}$ Wijaya, dkk,. Psikologi Pendidikan ( Jakarta: Mutiara.1994), hlm. 9. 
3. Tanggung jawab dalam bidang kemasyarakatan merupakan tugas guru yang mesti dapat menyukseskan pembangunan dalam bidang kemasyarakatan melului pendidikan, untuk itu guru harus mampu membimbing, mengabdi dan melayani masyarakat dan bersosialisasi.

4. Tanggung jawab guru dalam bidang keilmuan merupakan tugas yang harus diemban dalam memajukan ilmu pengetahuan, teknologi, bahasa dan seni agar tercipta peserta didik yang cerdas dan terampil

Oleh sebab itu kemampuan dan peranan guru sangat luas sekali. Dalam hal ini guru dituntut melakukan berbagai macam kompetensi agar dapat meningkatkan kemampuan peserta didik serta dapat membentuk karakter siswa yang berahlak dan dapat menjadi insan yang mandiri dan menjadi manusia yang seutuhnya.

\section{B. PEMBAHASAN}

Sebagai tenaga pendidik, negara menstandarkan guru mesti memiliki beberapa kompetensi, yaitu, paedagogik, kepribadian, sosial dan profesional (UU No. 14 Tahun 2005 Tentang Guru dan Dosen pasal 10 ayat 1). Keempat kompetensi tersebut menjadi modal utama guru dalam menjalankan profesinya. Dalam rangka meningkatkan salah satu kompetensi di bidang paedagogik yaitu dalam melaksakan keterampilan bertanya harus memperhatikan beberapa indicator yang berhubungan dengan keterampilan bertanya tersebut.

Dalam pembelajaran matematika keterampilan bertanya juga di perlukan dalam rangka melakukan aktivitas belajar mengajar di kelas dengan berbagai materi pokok bahasan yang berbeda-beda. Keterampilan bertanya, bagi seorang guru merupakan keterampilan yang sangat penting untuk dikuasai. Melalui keterampilan ini guru dapat menciptakan suasana pembelajaran lebih bermakna dan dapat melihat antusias siswa dalam menerima pembelajaran . Pembelajaran akan menjadi sangat membosankan, jika selama berjam-jam guru tiada hentinya menjelaskan materi pelajaran tanpa diselingi dengan pertanyaan, baik hanya sekedar pertanyaan pancingan, atau pertanyaan untuk mengajak siswa berpikir lebih serius ${ }^{4}$. Keterampilan bertanya adalah pada proses pengajaran itu sendiri, sebab pada umumnya guru dalam pengajarannya selalu melibatkan atau menggunakan tanya jawab. Keterampilan bertanya merupakan keterampilan seorang guru yang digunakan untuk mendapatkan jawaban atau balikan dari orang lain 5. Menurut Suherman satu hal yang penting dalam mengajar matematika adalah bertanya, karena dengan bertanya dapat mendorong siswa berpasipasipasi aktif dalam pembelajaran ${ }^{6}$. Melalui pertanyaan-pertanyaan yang relevan, guru dapat mengetahui pemahaman siswa tentang konsep matematika yang sudah dipahami dan yang belum dipahami.

Bertanya merupakan ucapan verbal yang meminta respons dari seseorang untuk mendaptakan jawaban. Respon yang diberikan dapat berupa pengetahuan sampai dengan hal-hal stimulasi efektif yang mendorong kemampuan berfikir siswa, seperti: (1) Merangsang kemampuan berfikir siswa dalam memecahkan

${ }^{4}$ Syaiful Bahri, Pembelajaran Dalam Implementasi Kurikulum Berbasis Kompetensi (Jakarta: PT Rineka cipta, 2000), hlm. 157.

${ }^{5}$ Supriyadi, Strategi Belajar \& Mengajar (Yogyakarta: Jaya Ilmu, 2013), hlm. 158.

${ }^{6}$ Suherman, Erman, Strategi Pembelajaran Matematika Kontemporer (Bandung: JICA UPI.2001), hlm. 189-191. 
masalah; (2) Membantu siswa aktif dalam belajar; (3) Mengarahkan siswa pada tingkat interaksi belajar yang mandiri; (4) Meningkatkan kemampuan berfikir siswa dari kemampuan berfikir tingkat rendah ke tingkat yang lebih tinggi; dan (4) Membantu siswa dalam mencapai tujuan pelajaran yang dirumuskan.

Agar siswa tidak merasa bosan dan jenuh guru dapat melakukan berbagai variasi dalam menggunakan keterampilan bertanya. Keterampilan bertanya dalam mengajar dibagi dua yaitu keterampilan dasar mengajar tingkat dasar dan keterampilan dasar mengajar tingkat lanjut. Keterampilan dasar mengajar tingkat dasar dapat dilakukan guru dengan menerapkan mengajukan pertanyaan. Keterampilan dasar mengajar tingkat lanjut merupakan lanjutan dari keterampilan dasar mengajar tingkat dasar dan berfungsi untuk mengembangkan kemampuan berpikir siswa, meningkatkan keaktifan siswa, dan mendorong siswa agar mengambil inisiatif sendiri ${ }^{7}$.

Bertanya merupakan salah satu unsur dalam suatu proses komunikasi antara guru dengan peserta didik, yang dilakukan di dalam pembelajaran. Keterampilan bertanya merupakan ucapan atau pertanyaan yang dilontarkan guru sebagai dorongan, untuk memunculkan atau menumbuhkan jawaban (respon) dari peserta didik sekaligus melihat tingkat keberhasilan dalam mencapai tujuan pembelajaran. Ada hal penting dalam keterampilan bertanya yaitu :

\section{Pausing}

Dalam kegiatan pausing ini guru dapat mengajukan pertanyaan dalam bidang aljabar misalnya hasil dari $(2 \mathrm{a}-\mathrm{b})(2 \mathrm{a}+\mathrm{b})$ adalah........Pemfaktoran dari $4 x^{2}-9 x^{2}$ adalah.....selanjutnya murid diminta diam dan tenang sebentar, ini bertujuan untuk memberikan kesempatan berpikir mencari jawaban secara komplit dan dapat menurunkan jawaban.

\section{Prompting}

Promting sangat perlu dilakukan guru agar dapat mengajukan pertanyaan "sulit", sehingga tidak ada murid yang dapat menjawab, karena sulitnya, atau karena pertanyaan tidak jelas. Oleh sebab itu guru harus melakukan "prompt" mengarahkan dan mendorong, Prompting, situasi diskusi tidak hanya berjalan lancar tetapi guru mampu memfasilitasi semua siswa dan mengantarkan siswa kepada pengetahuan baru yang ingin dicapai sebagai hasil dari proses berpikir mereka. misalnya soal dalam bidang aritmatika yaitu suatu barisan aritmatika dengan suku ke-3 adalah 10 dan suku ke-9 adalah 28. Tentukan jumlah 16 suku pertama dari barisan tersebut. Maka seorang guru dapat memberikan informasi tambahan seperti harus mencari beda dan suku pertama dari barisan aritmatika tersebut sehingga dapat diselesaikan secara tuntas dan benar seperti penyelesaian di bawah ini.

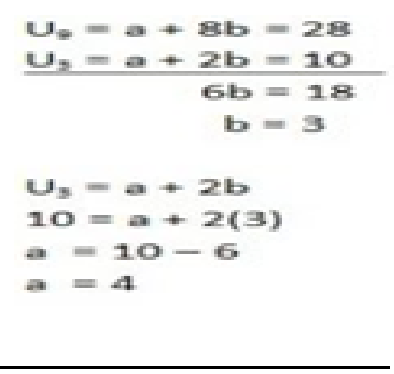

${ }^{7}$ Udin Syaefudin Saud, Pengembangan Profesi Guru.( Bandung: Alfabeta, 2009), hlm. 


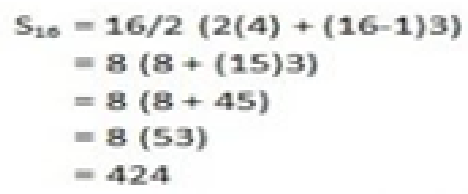

Jadi jumlah 15 suku pertama dari barisan aritmatika di atas adalah 424

\section{Probing}

Melacak, menuntun, mengarahkan. Probing dilakukan karena belum diperoleh jawaban yang memuaskan. Untuk memperoleh jawaban yang sempurna, maka guru menunjuk murid lain untuk menjawab. Apabila belum puas, minta murid yang lain lagi. Yang akhirnya diperoleh jawaban yang sempurna ${ }^{8}$. Guru dapat bertanya tentang materi lingkaran, misalnya tentukan persamaan garis singgung melalui titik $(2,-3)$ pada lingkaran $\mathrm{x}^{2}+\mathrm{y}^{2}=13$, ketika siswa A di tunjuk dan tidak mampu menyelesaikannya secara benar maka guru dapat menunujuk siswa Si B untuk mendapatkan jawaban yang sempurna.

Dalam mengembangkan bertanya probing ini perlu diketahui teori belajar yang melandasinya yaitu teori konstruktivisme yang dikembangkan oleh Jean Piaget mengungkapkan bahwa siswa sebaiknya membangun secara aktif pengetahuannya sendiri. Pandangan konstruktivis tentang pembelajaran menyatakan siswa seyogianya diberi kesempatan untuk dapat memkontruksikan pengetahuannya sendiri agar dapat menggunakan strategi sendiri dalam belajar secara sadar dan guru membimbing siswa ke tingkat pengetahuan yang lebih tinggi.

Menurut Sudjana dalam Gintings, bahwa penganut teori kontruktivistik memandang upaya mentransfer pengetahuan adalah pekerjaan yang sia-sia. ${ }^{9}$ Hal senada Driver dalam Suparno, mengungkapkan beberapa prinsip konstruktivisme, yaitu : (a) Pengetahuan dapat dibangun oleh siswa sendiri, baik secara personal maupun sosial; (b) Pengetahuan tidak dapat dipindahkan dari guru ke siswa kecuali dengan keaktifan siswa dalam pembelajaran; (c) Siswa harus dapat aktif mengkonstruksi terus menerus pengetahuannya, sehingga selalu terjadi perubahan konsep menuju konsep yang lebih rinci, lengkap serta sesuai dengan konsep; (d) Guru sekedar membantu menyediakan sarana dan situasi (fasilitator) agar proses konstruksi siswa berjalan mulus ${ }^{10}$. Prinsip dasar dari semua pengajaran efektif adalah menggunakan pertanyaan (questioning) dalam ruang kelas . Namun tidak semua pengajuan pertanyaan yang dilakukan oleh guru dapat dinilai efektif untuk keberlangsungan pembelajaran. Pengajuan pertanyaan dinilai efektif jika pertanyaan tersebut dapat meningkatkan motivasi siswa dalam belajar, mengantarkan guru kepada tujuan-tujuan pelajaran, serta tujuan-tujuan khusus khusus dari teknik questioning sendiri ${ }^{11}$.

Pada dasarnya ada tiga kemungkinan yang terjadi ketika seorang guru mengajukan pertanyaan kepada siswa. Kemungkinan tersebut adalah siswa menjawab dengan benar, salah, atau diam. Guru kemudian berpindah kepada

${ }^{8}$ Bukhari Alma, dkk, Guru Professional (Bandung: Alfabeta, 2009), hlm. 24.

9 Ginting, Abdurrahman, Esensi Praktis Belajar \& Pembelajaran (Bandung: Humaniora.2008), hlm. 29.

10 Suparno, Paul, Filsafat Konstruktivisme dalam Pendidikan (Yogyakarta: Kanisius, 1996), hlm. 49

${ }^{11}$ Eggen, P. D., Kauchak, D. P. dan Harder, R. J., Strategies for Teachers (New Jersey: Prentice-Hall IncEnglewood Cliffs.1998), hlm. 172. 
siswa lain dengan tujuan untuk menjaga kelancaran pembelajaran. Sayangnya, melakukan hal semacam itu akan membuat siswa tersebut menjadi bingung, kecil hati dan secara pisikologis merasa terusir dari diskusi namun, dengan menerapkan teknik keterampilan bertanya dalam proses pembelajaran matematika sangat penting sekali diperhatikan seorang guru matematika, dengan tujuannya melihat sejauh mana ketercapaian tujuan pembelajaran tercapai. Sesuai pendapat Eni keterampilan bertanya sangat penting dilakukan dengan alasan (1) Telah berakarnya mengajar dengan menggunakan metode ceramah yang cenderung menempatkan guru sebagai sumber informasi (Teacher Center) sedangkan siswa menjadi penerima informasi yang pasif (Student Center) (2) Latar belakang kehidupan anak dalam lingkungan keluarga dan masyarakat yang kurang biasa mengajukan pertanyaan dan menyatakan pendapat,(3) Penggalakan penerapan gagasan active learning saat ini yang menuntut para siswa lebih banyak terlibat secara mental dalam proses belajar-mengajar seperti bertanya pada saat materi tidak dimengerti, berusaha menemukan jawaban masalah yang dihadapinya (4) Pandangan yang salah mengenai tujuan pertanyaan yang mengatakan bahwa pertanyaan hanya digunakan untuk mengevaluasi hasil belajar siswa ${ }^{12}$.

Dalam pembelajaran matematika guru perlu mengetahui bagaimana pertanyaan seorang guru yang baik. Agar pembelajaran berhasil dan bermakna tentu sejumlah pertanyaan yang akan diberikan harus dapat diterima dan dipahami siswa. Adapun tahapan-tahapan dasar-dasar pertanyaan yang baik adalah sebagai berikut:

1) Jelas dan mudah dipahami oleh siswa

2) Berikan informasi yang cukup dan luas untuk menjawab pertanyaan

3) Difokuskan pada suatu masalah atau tugas tertentu

4) Berikan waktu yang cukup kepada anak untuk berpikir sebelum menjawab pertanyaan yang diajukan

5) Berikan semua pertanyaan kepada seluruh murid secara merata

6) Berikanlah respon yang ramah, bersahabat dan menyenangkan sehingga timbul keberanian siswa untuk menjawab atau bertanya kepada guru

7) Tuntunlah jawaban siswa dengan baik sehingga mereka dapat menemukan sendiri jawaban yang benar ${ }^{13}$.

\section{a) Komponen-Komponen Bertanya}

Untuk melihat sejauh mana tentang kemampuan siswa dalam menguasai pembelajaran matematika yang disampaikan maka guru perlu mengajukan beberapa pertanyaan.. Pertanyaan yang di sampaikan harus memperhatikan komponen;komponen keterampilan bertanya. Oleh sebab itu keterampilan bertanya dapat dibagi menjadi dua kelompok yaitu keterampilan bertanya dasar dan keterampilan bertanya lanjutan ${ }^{14}$ :

1) Keterampilan Bertanya Dasar, adapun komponen keterampilan bertanya dasar adalah:

12 Eni Purwati dkk, Microteaching (Surabaya: Aprinta, 2009), hlm. 6-15.

${ }^{13}$ User Usman, Menjadi Guru Professional (Bandung: PT Remaja Rosda Karya, 2005), hlm. 75

${ }^{14}$ Kusnadi, Profesi dan Etika Keguruan (Pekan Baru: Yayasan Pustaka Riau, 2011), hlm. 78. 


\section{a. Jelas dan singkat}

Pertanyaan hendaknya singkat dan jelas, dengan kata-kata yang dipahami siswa. Pertanyaan yang berbelit-belit tidak akan dipahami sehingga kemungkinan besar siswa tidak dapat menjawabnya. Susunan kata-kata harus disesuaikan dengan usia dan tingkat perkembangan siswa. Contoh pertanyaan yang dapat diajukan pada siswa yang duduk pada tingkat SLTP, berapakah jumlah sudut dalam segitiga? sebutkan jenis-jenis segitiga dan sebagainya

\section{b. Pemberian acuan}

Sebelum mengajukan pertanyaan, kadang-kadang guru perlu memberi acuan pertanyaan yang berisi informasi yang relevan dengan jawaban yang diharapkan dari siswa. Pemberian acuan ini akan banyak menolong siswa untuk mengarahkan pikirannya kepada pokok bahasan yang sedang dibahas dalam pedoman kerja guru ${ }^{15}$. Pertanyaan dalam pembelajaran matematika dapat di ambil contohnya tentukan nilai dari $\sin 75^{\circ}$ !

Maka guru dapat membuat acuan dengan menuliskan rumus penjumlahan $\sin (\alpha+\beta)=\sin \alpha \cos \beta+\cos \alpha \sin \beta$ sehingga siswa dapat menjawab dengan baik dan benar seperti di bawah ini

$$
\begin{aligned}
\sin 75^{\circ} & =\sin \left(45^{\circ}+30^{\circ}\right) \\
& =\sin 45^{\circ} \cos 30^{\circ}+\cos 45^{\circ} \sin 30^{\circ} \\
& =1 / 2 \sqrt{2} \cdot 1 / 2 \sqrt{3}+1 / 2 \sqrt{2} \cdot 1 / 2 \\
& =1 / 4 \sqrt{6}+1 / 4 \sqrt{2} \\
& =\mathbf{1} / \mathbf{4}(\sqrt{6}+\sqrt{2})
\end{aligned}
$$

\section{c. Pemusatan}

Pertanyaan yang dilontarkan guru dapat dibagi menjadi beberapa bentuk pertanyaan yaitu pertanyaan luas dan pertanyaan sempit. Pertanyaan luas ketika guru menuntut jawaban yang umum dan cukup luas, sedangkan pertanyaan sempit ketika guru menuntut jawaban yang khusus spesifik. Pertanyaan yang sempit menuntut pemusatan perhatian siswa pada hal-hal yang khusus yan perlu didalami. Pertanyaan dalam bentuk luas dalam pembelajaran matematika dapat di ajukan seperti: tuliskan semua rumusrumus identitas dalam trigonometri yang anda ketahui! Dan pertanyaan sempit dapat di buat pertanyaan seperti: sederhana.

Nyatakan setiap bentuk berikut ke dalam faktor-faktor yang paling

a. $\left(1-\cos ^{2} \beta\right)=\ldots \ldots$

b. $\left(\sin ^{2} \alpha-\cos ^{2} \alpha\right)=\ldots$ maka jawaban siswa secara kuhusus seperti di bawah ini

Maka siswa menjawab secara khusus dengan langkah-langkah berikur ini

a. $1-\cos ^{2} \beta$

Dari identitas $\left(\sin ^{2} \beta+\cos ^{2} \beta\right)=1$, maka diperoleh

$\Rightarrow\left(1-\cos ^{2} \beta\right)=\sin ^{2} \beta$

Jadi, $\left(1-\cos ^{2} \beta\right)=\sin ^{2} \beta$.

b. $\left(\sin ^{2} \alpha-\cos ^{2} \alpha\right)=\ldots$

Dari identitas $\left(\sin ^{2} \alpha+\cos ^{2} \alpha\right)=1$, maka $\sin ^{2} \alpha=\left(1-\cos ^{2} \alpha\right.$.)

15 Noerhadi Th, Sri Anita Wiryawan, Strategi Belajar Mengajar (universitas terbuka, 1994), hlm. 8-4. 


$$
\begin{aligned}
& \Rightarrow \sin ^{2} \alpha-\cos ^{2} \alpha=\left(1-\cos ^{2} \alpha-\cos ^{2} \alpha\right) \\
& \Rightarrow \sin ^{2} \alpha-\cos ^{2} \alpha=\left(1-2 \cos ^{2} \alpha\right) \\
& \text { Karena }\left(2 \cos ^{2} \alpha-1\right)=\cos 2 \alpha, \text { maka }\left(1-2 \cos ^{2} \alpha\right)=-\cos 2 \alpha . \\
& \Rightarrow\left(\sin ^{2} \alpha-\cos ^{2} \alpha\right)=-\cos 2 \alpha \\
& \text { Jadi, }\left(\sin ^{2} \alpha-\cos ^{2} \alpha\right)=-\cos 2 \alpha .
\end{aligned}
$$

\section{d. Pemindahan giliran}

Ada kalanya sebuah pertanyaan lebih-lebih pertanyaan yang cukup kompleks, tidak dapat dijawab secara tuntas oleh seorang siswa. Dalam hal ini, guru perlu memberikan kesempatan kepada siswa lain dengan cara pemindahan giliran. Artinya, setelah siswa pertama memberi jawaban, guru meminta siswa kedua melengkapi jawaban tersebut, kemudian meminta lagi siswa ketiga dan seterusnya. Pertanyaan ini dapat di ajukan pada contoh di bawah ini.

Jika $3^{\mathrm{a}}=5$ dan $5^{\mathrm{b}}=2$, maka nilai dari ${ }^{15} \log 40$ adalah $\ldots .$.

Apabila pertanyaan ini tidak dapat di jawab siswa yang tunjuk maka guru dapat meminta siswa lain untuk menjawabnya sehingga jawabannya benar dengan menggunakan langkah-langkah berikut:

$$
\begin{aligned}
& \text { Ingat rumus } a^{b}=c \Leftrightarrow b={ }^{a} \log c \\
& \text { maka } 3^{a}=5 \Leftrightarrow a={ }^{3} \log 5 \text { dan } 5^{b}=2 \Leftrightarrow b={ }^{5} \log 2 \\
& { }^{15} \log 40=\frac{{ }^{5} \log 40}{{ }^{5} \log 15} \\
& =\frac{{ }^{5} \log 2^{3} \cdot 5}{{ }^{5} \log 3 \cdot 5} \\
& =\frac{{ }^{5} \log 2^{3}+{ }^{5} \log 5}{{ }^{5} \log 3+{ }^{5} \log 5} \\
& =\frac{3 \cdot{ }^{5} \log 2+{ }^{5} \log 5}{{ }^{5} \log 3+{ }^{5} \log 5} \\
& =\frac{3 b+1}{\frac{1}{a}+1}
\end{aligned}
$$

Kalikan $\quad \frac{\mathrm{a}}{\mathrm{a}}$ dengan, didapat

$$
\frac{3 b+1}{\frac{1}{a}+1}=\frac{3 a b+a}{1+a}
$$

\section{e. Penyebaran}

Penyebaran pertanyaan berarti menyebarkan giliran untuk menjawab pertanyaan yang diajukan guru. Teknik penyebaran perlu diperhatikan guru, lebih-lebih bagi guru yang biasa mengajukan pertanyaan pada siswa tertentu. Ada kalanya guru melupakan siswa yang duduk dideretan belakang, sehingga aman untuk dari kejaran guru. Agar pertanyaan mendapat giliran semua, guru dapat membuat pertanyaan sebanyak jumlah siswa, tetapi dalam menjawab pertanyaan perlu bimbingan guru ketika ada siswa yang tidak mampu menjawab. 


\section{f. Pemberian waktu berpikir}

Dalam menjawab suatu pertanyaan yang dilontarkan guru maka peserta didik memerlukan waktu untuk berpikir. Seorang guru jangan hendaknya tergesa -gesa dalam menagih jawaban peserta didik. Oleh sebab itu berikan waktu berpikir untuk menjawab pertanyaan tersebut dan agar siswa dapat menjawab dengan jelas tanpa merasa terbebani dengan jawaban yang tidak pasti.

\section{g. Pemberian tuntunan}

Beberapa pertanyaan yang dilontarkan guru kepada peserta didik tidak seluruhnya dapat dijawab dengan tepat. Dalam kesempatan ini guru harus dapat menuntun siswa secara bertahap sehingga jawabannya mengarah kepada jawaban yang sempurna. Jawaban yang kurang tepat tidak bisa dibiarkan begitu saja sehingga peserta didik yang lain dapat mencontoh jawaban yang benar. Untuk lebih mengarahkan jawaban yang tepat guru dapat mengarahkan ataupun memberikan tuntunan sebagai berikut (1) Memfrase, yaitu mengajukan kembali pertanyaan dengan cara lain yang lebih mudah dan sederhana, sehingga lebih dipahami oleh siswa, (2) Mengajukan pertanyaan lain yang lebih sederhana yang dapat menuntun siswa menemukan jawabannya,(3) Mengulangi penjelasan/ informasi sebelumnya yang berkaitan dengan pertanyaan yang diajukan ${ }^{16}$.

\section{2) Keterampilan Bertanya Tingkat Lanjutan}

Tahapan selanjutnya adalah keterampilan bertanya tingkat lanjut. Seorang guru dapat melanjutkan dari tahapan keterampilan bertanya dasar . Keterampilan tingkat lanjut ini merupakan pertanyaan yang di ajukan seorang guru lebih spesifik. Keterampilan tingkat lanjut yang dilakukan guru hendaknya peserta didik lebih dapat menguasai kompetensi dasar sesuai dengan tujuan pembelajaran. Adapaun keterampilan bertanya tingkat lanjut di bagi beberapa bagian yaitu:

a. Pengubahan tuntunan tingkat kognitif, Pertanyaan yang diajukan guru harus mampu menuntun peserta didik dari pertanyaan tingkat kognitf yang hanya sekedar mengingat fakta menuju pertanyaan yang lebih luas dan mendalam, seperti pemahaman, penerapan, analisis, sintesis, dan evaluasi. Berdasarkan pengubahan tuntunan ini peserta didik dapat menguasai taksonomi Bloom dalam bidang kognitif mulai dari $\mathrm{C}_{1}$ sampai $\mathrm{C}_{6}$

b. Pengaturan urutan pertanyaan, Dalam melontarkan pertanyaan seorang guru tidak boleh sesuka hatinya mengajukan sebuah pertanyaan kepada siswa tanpa memberi urutan yang jelas. Bentuk pertanyaan hendaknya mulai dari yang lebih sederhana menuju yang paling kompleks secara berurutan atau dengan kata lain pemberian pertanyaan yang mudah menuju kepertanyaan yang sulit. Guru hendaknya menghindari pertanyaan bolak balik dari yang mudah atau yang sederhana kepada yang sukar kemudian kepada yang sukar lagi.

c. Pertanyaan pelacak, Jika jawaban yang diberikan peserta didik belum sempurna atau kurang tepat maka guru dapat memberikan pertanyaan pelacak. Pertanyaan pelacak ini bertujuan untuk memudahkan peserta

\footnotetext{
${ }^{16}$ Djadja Djadjuri, Strategi Belajar Mengajar (1994), hlm. 7-10.
} 
didik memberi jawan yang tepat dan sempurna. Pertanyaan pelacak dapat dilakukan dengan beberapa cara::

(1) Klarifikasi, Seorang guru dapat melacak jawaban peserta didik dengan memberikan pertanyaan lanjutan atau pertanyaan lacakan dan ini dilakukan jika jawaban peserta didik kurang sempurna dan kurang tepat selanjutnya peserta didik tersebut mampu mengungkapkan kembali dengan kalimat lain yang lebih jelas.

(2) Meminta peserta didik memberikan alas an dari jawaban yang diajukan. Peserta didik harus dapat memberi alasan yang tepat dan jelas dari pertanyaan yang diajukan oleh guru kepada peserta didik. Alasan yang dikemukakan peserta didik tersebut harus sesuai dengan fakta yang akurat serta dapat dipertanggung jawabkan secara keilmuwan.

(3) Meminta jawaban bersama. Untuk memperoleh kesepakatan bersama tentang jawaban yang tepat maka seorang guru dapat mengajukan pertanyaaan kepada beberapa siswa. Pertanyaan yang diajukan ini tentunya mempunyai jawaban yang beragam. Melalui jawaban yang tidak sama antara siswa yang satu dengan siswa yang lain maka guru beserta peserta didik dapat menyimpulkan jawaban bersama.

(4) Meminta jawaban yang tepat, Jawaban yang di kemukakan siswa bisa saja kurang mencapai sasaran seperti yang diharapkan maka guru dapat mengajukan pertanyaan lanjutan.

(5) Meminta jawaban yang lebih relevan. Seorang guru dapat memperoleh jawaban yang lebih relevan atau sesuai dengan tujuan pembelajaran maka hendaknya guru melakukan keterampilan bertanya tingkat lanjut. Seorang guru dapat mencek apakah jawaban peserta didik itu sesuai dengan pokok bahasan yang di ajarkan melalui indicator kompetensi dasar

(6) Meminta contoh yang lebih spesifik. Dalam kegiatan ini guru dapat memberi pertanyaan lanjutan apabila jawaban yang diajukan peserta didik belum jelas tujuannya. Dalam hal ini guru meminta jawaban yang berupa contoh ilustrasi. Sehingga jawaban ilustrasi yang di kemukakan oleh peserta didik memudahkan membuat contoh berikutnya.

(7) Meminta jawaban yang lebih kompleks. Pertanyaan lanjutan diberikan guru apabila terjadi jawaban yang diajukan peserta didik masih sederhana atau kurang lengkap. Dengan pertanyaan lanjutan yang diberikan guru dapat memperluas jawaban siswa sesuai dengan indikator pencapaiuan kompetensi dasar. .

\section{d. Mendorong terjadinya interaksi}

Untuk mendorong terjadinya interaksi di dalam kelas, hal yang harus diperhatikan oleh guru adalah :

(1) Pertanyaan yang diajukan guru hendaknya dijawab oleh peserta didik, tetapi seluruh peserta didik diberi kesempatan singkat untuk mendiskusikan jawabannya bersama teman dekatnya.

(2) Guru hendaknya menjadi dinding pemantul, jika ada peserta didik yang mengajukan pertanyaan, janganlah dijawab langsung, tetapi 
berikan kesempatan kepada peserta didik yang lain untuk menjawabnya atau dapat didiskusikan dalam forum kelas ${ }^{17}$.

\section{b) Tujuan Keterampilan Bertanya}

Keterampilan bertanya yang dilakukan guru, tentu mempunyai tujuan yang sangat baik terhadap aktivitas yang dilaksanakan di kelas. Pertanyaan yang di lontarkan akan membawa perubahan yang positif terhadap peningkatan kemampuan siswa dalam meningkatkan kemampuan -kemampuan yang akan di capai. Menurut Sanjaya, pertanyaan yang baik, memiliki dampak yang positif terhadap siswa, diantaranya ${ }^{18}$ : (1) Dapat meningkatkan partisipasi siswa secara penuh dalam proses pembelajaran; (2) Dapat meningkatkan kemampuan berpikir siswa, sebab berpikir itu sendiri hakikatnya bertanya; (3) Dapat membangkitkan rasa ingin tahu siswa, serta menuntun siswa untuk menentukan jawaban; (4) Memusatkan siswa pada masalah yang dibahas.

Keterampilan bertanya yang baik akan membawa dampak yang baik terhadap siswa dan dapat merangsang keaktifan dalam proses pembelajaran matematika. Antara lain: (1) Merangsang kemampuan berpikir yang lebih efektif; (2) Membantu siswa dalam belajar; (3) Menuntun siswa pada interaksi belajar yang mandiri; (4) Membantu siswa dalam mencapai tujuan pelajaran yang dirumuskan dalam kompetensi dasar; (5) Memusatkan kekuatan ingatan dalam suatu masalah, sehingga dapat mengikuti sepenuhnya pembahasan dan pendalaman masalahnya, kemudian setelah itu bepindah kepada bahan lain (bahan baru); (6) Memantapkan pemahaman tentang pengertian-pengertian dan masalahmasalah yang telah diajarkan kepada mereka; (7) Mengukur (mengevaluasi) benar tidaknya bahan pelajaran yang dapat mengerti / ditangkap oleh murid-murid selama pelajaran berlangsung dan mengukur kadar jelas tidaknya (pengertian mereka); (8) Akan jelas bagi guru, banyaknya pelajaran yang sudah diketahui/dimengerti oleh murid-muridnya dan sebagai pedoman untuk melanjutkan materi yang akan datang. ${ }^{19}$

\section{c) Cara Membangkitkan Motivasi Bertanya Siswa}

Dalam segala bentuk proses pembelajaran matematika yang dilakukan guru, tidak terlepas dari keterampilan bertanya. Oleh sebab itu bertanya yang ditujukan kepada siswa harus mampu membangkitkan motivasi siswa yang tujuannya ingin mengetahui lebih jauh tentang materi yang disampaikan. .Dalam proses belajar mengajar di dalam kelas tentunya tidak semua siswa mampu bertanya. terkadang menjumpai anak yang kurang antusias mengikuti pembelajaran. Kurangnya akntusias atau minat ini ditandai dengan kurang aktifnya siswa bertanya dalam pembelajaran. maka dari itu ada 4 cara untuk membangkitkan semangat siswa dengan cara.

1) Guru memberikan reward (poin) bagi setiap siswa yang bertanya, satu poin untuk pertanyaan yang tidak sesuai dengan materi pembelajaran, dan dua poin untuk pertanyaan yang sesuai dengan materi pembelajaran. poin tersebut dapat berupa tambahan nilai ulangan harian atau sekedar ucapan,

17 E Mulyasa, Menjadi Guru Professional (Bandung: Pt Remaja Rosda Karya, 2005), hlm. 73-77.

18 Wina,Sanyaya, Pembelajaran dalam Implementasi Kurikulum Berbasis Kompetensi (Jakarta: Rosda Karya, 2005), hlm.157.

19 Abu Bakar Muhammad, Pedoman Pendidikan dan Pengajaran, (Surabaya: Usaha Nasional, 1981), hlm. 92. 
misalnya "pertanyaan yang bagus". Hal itu di perkuat oleh Usman bahwa reward adalah suatu motivasi dalam mencapai tujuan pembelajaran, keberhasilan untuk mencapai tujuan yang memuaskan motivasinya dianggap sebagai hadiah,ganjaran, pujian atau balasan yang menimbulkan perasaan senang dan gembira dan puas.$^{20}$

2) Guru memberi pertanyaan pada siswa yang pasif untuk di jawab. Beri satu poin jika jawaban salah, dan beri dua poin jika jawaban benar. Ketika jawabannya kurang tepat guru dapat meminta siswa tersebut untuk mencari bantuan temannya guna menjawab pertanyaan tersebut dengan benar.

3) Menyebut nama siswa tertentu yang relatif aktif atau antusias dalam mengikuti pembelajaran. Misalnya, di sela-sela penjelasan diikuti dengan penyebutan "si A juga kalau belajar keras bisa jadi juara”. Hal ini di maksud untuk menjalin hubungan emosional guru-siswa secara hangat.

4) Menggunakan strategi pembelajaran yang efektif untuk meningkatkan motivasi siswa untuk bertanya, seperti strategi pembelajaran "every one is a teacher here"

Dengan demikian bahwa dalam membangkitkan motivasi siswa untuk bertanya maka seorang guru matematika dapat memberikan rewad dalam rangka menunjang berbagai hal yang positif terhadap peserta didik dan menjadi pendorong atau motivasi agar belajar lebih baik lagi. Pemberian reward ini dalam proses belajar mengajar merupakan bentuk motivasi yang berorientasi pada keberhasilan belajar atau prestasi peserta didik Memberikan reward terhadap siswa sangat penting dilakukan oleh guru, agar peserta didik merasa mendapat perhatian, penghargaan dan dorongan bila melakukan suatu tindakan dalam memecahkan masalah sesuai dengan kemampuannya.

\section{KESIMPULAN}

Keberhasilan seorang guru matematika dalam menyampaikan pembelajaran di kelas tidak terlepas dari keterampilan bertanya. Keterampilan bertanya ini sangat penting di lakukan guru sebagai salah satu alat penilaian kepada siswa dan juga dapat mengaktifkan kegiatan belajar mengajar. Keterampilan bertanya yang dilakukan dalam proses belajar mengajar matematika merupakan bagian yang tidak terpisahkan dari seluruh rangkaian mulai dari pembukaan pembelajaran sampai kepada penutup pembelajaran dalam rangka meningkatkan kualitas proses dan hasil pembelajaran, yang sekaligus merupakan bagian dari keberhasilan dalam pengelolaan intruksional dan pengelolaan kelas. Melalui keterampilan bertanya guru harus mampu mendeteksi hambatan proses berifikir di kalangan siswa dan dapat memperbaiki serta meningkatkan proses belajar di kalangan siswa.

\section{DAFTAR PUSTAKA}

Abu Bakar Muhammad, Pedoman Pendidikan dan Pengajaran, Surabaya: Usaha Nasional, 1981.

20 Usman Najati, Muhammad, Psikologi Dalam Al-Qur'an, terj. M. Zaka Al-Farisi (Bandung: Pustaka Setia, 2005). 
Bukhari Alma, dkk, Guru Professional, Bandung: Alfabeta, 2009.

Djadja Djadjuri, Strategi Belajar Mengajar, 1994.

E Mulyasa, Menjadi Guru Professional, Bandung: PT Remaja Rosda Karya, 2005.

Eggen, P. D., Kauchak, D. P. dan Harder, R. J. Strategies for Teachers. New Jersey: Prentice-Hall Inc Englewood Cliffs, 1998.

Eni Purwatidkk, Microteaching, Surabaya: Aprinta, 2009.

Ginting, Abdurrahman, Esensi Praktis Belajar \& Pembelajaran. Bandung: Humaniora, 2008.

Hamalik, Dasar-dasar Pengembangan Kurikulum. Cet. III, Bandung: Remaja Rosda Karya, 2000.

Kusnadi, Profesi dan Etika Keguruan, Pekan Baru: Yayasan Pustaka Riau, 2011.

Noerhadi, Th, Sri Anita Wiryawan, Strategi Belajar Mengajar, Universitas Terbuka, 1994.

Sudjana. Metoda Statistika, Edisi ke VI. Bandung: Tarsito, 2002.

Syaiful Bahri, Pembelajaran Dalam Implementasi Kurikulum Berbasis Kompetensi, Jakarta: PT Rineka cipta, 2000.

Supriyadi, Strategi Belajar \& Mengajar, Yogyakarta: Jaya Ilmu, 2013.

Suherman, Erman, Strategi Pembelajaran Matematika Kontemporer, Bandung: JICA UPI, 2001.

Suparno, Paul, Filsafat Konstruktivisme dalam Pendidikan, Yogyakarta: Kanisius, 1996.

Udin, Syaefudin Saud, Pengembangan Profesi Guru, Bandung: Alfabeta, 2009.

Usman, Menjadi Guru Professional, Bandung : PT Remaja Rosda Karya, 2005.

Usman Najati, Muhammad. Psikologi Dalam Al-Qur'an, terj. M. Zaka Al-Farisi, Bandung: Pustaka Setia, 2005.

Wijaya, dkk, Psikologi Pendidikan, Jakarta: Mutiara, 1994.

Wina, Sanyaya. Pembelajaran dalam Implementasi Kurikulum Berbasis Kompetensi, Jakarta: Rosda Karya, 2005. 